\title{
The Effect of Waste Management Training on Entrepreneurship Motivation
}

\author{
Surahma Asti Mulasari ${ }^{1}$ and Fatwa Tentama ${ }^{2, *}$ \\ ${ }^{1}$ Faculty of Public Health, Ahmad Dahlan University, Yogyakarta, Indonesia \\ ${ }^{2}$ Faculty of Psychology, Ahmad Dahlan University, Yogyakarta, Indonesia
}

\begin{abstract}
This research aimed at finding the effect of waste management training on people's entrepreneurship motivation. The people's enterprise motivation in converting waste into bio charcoal, liquid organic fertilizer, and plant growth medium is still shallow due to their lack of knowledge and skill in handling waste. The subject of the research consisted of 30 male and female, married, unemployed and villagers of Gondang Legi and Kepuh. The experimental design used One-Group Pretest-Postest Design. The data analysis technique used Wilcoxon's nonparametric statistical test. The result of the analysis showed $Z=-2.183$ and 0.0145 (1-tailed), with $p<0.05$, which showed that there was a significant entrepreneurship motivation difference of the people before and after the training of waste management. The training was effective in improving the people's motivation.
\end{abstract}

Keywords: Entrepreneurship Motivation, Waste Management, Briquet of Charcoal, Liquid Organic Fertilizer, Plant Growing Medium.

\section{INTRODUCTION}

Nowadays the problem of big overpopulated countries is the waste. The increasing number of waste is caused by their life style and financial capability. The higher their income is, the more waste they produce. ${ }^{1}$ Besides the growing industry and population explosion resulted in the significant increase of waste. ${ }^{2}$ But the increasing number of waste is not accompanied by proper waste management so that the waste problem becomes more complicated. The waste problem and its management appear in Zimbabwe. The people still litter, they lack infrastructure and waste facilities. ${ }^{3}$ Indian Mumbai faces the problem of waste and inefficient waste management. ${ }^{4}$ The urban waste management problem in India is related to the budget, infra structure, planning, operational data, and leadership. ${ }^{5}$ Nigerian Kano Metropolis faces the problems of policy in waste management, budget, infra structure, and technical matters of waste management. ${ }^{2}$ Nigerian Ibadan faces other problems involving the people's lack of environmental awareness, human resources, and infra structure, urban planning, and budget. ${ }^{6}$ Nigerian Lagos Municipality faces the problem of illegal littering and garbage piling up. ${ }^{7}$

In Indonesia, most waste comes from the household. Every day a family regularly produces 0.8 kilograms of waste. ${ }^{8}$ Waste gets piled up so that it spoils the environment. It needs handling. Also, the people are still careless in handling waste so that it affects environment and health. ${ }^{9}$ They need knowledge and skills

\footnotetext{
${ }^{*}$ Author to whom correspondence should be addressed.
}

in waste handling. Recent researches on waste handling and management were done such as done by Hotagaol, ${ }^{10}$ Noosom, ${ }^{11}$ and Choe and Fraser. ${ }^{12}$ The policy of waste management, recycling system, waste transport and disposal, and budget effectiveness. ${ }^{13}$ Waste management is the most important thing to do. The system of waste management is needed to reduce the impact waste on human health and environment. ${ }^{14}$

This research was done in Sleman regency, Yogyakarta particular province, Indonesia precisely at Gondang Legi and Kepuh villages, which were far from the city. The people here did not get the waste handling service due to their remote positions so that they had to manage their waste themselves. ${ }^{15}$ The result of observation and interview indicated that the people in the area showed their low motivation to make use of the abundant waste due to their lack of knowledge and skills in waste handling so that environmental pollution cannot be avoided. Various garbage was everywhere and piled up along the streets, at river banks, and at empty spaces. Littering was a common practice. The people needed help and encouragement to handle the waste independently. Motivation is the primary capital to do so. This involved activation of energy, direction, and persistent will. Lourat explains that motivation is shown as a connection between internal power activation and something released to create a business. ${ }^{16}$ Entrepreneurship motivation is an important aspect of doing entrepreneurship. ${ }^{17}$

According to the interview with the subject of the study, they said that they were not interested in doing an entrepreneurship to handle waste because they had little knowledge and skills in 
managing waste, so they were afraid of doing the entrepreneurship for fear that they failed, less confident, indecisive for they were lack of capital. Seeing the fact, it was necessary for them to have training on waste management to improve their motivation in the field. It is the entrepreneurship motivation that in the end will change their attitudes and behavior in waste handling, improve their economy and overcome pollution problems. Riyanti ${ }^{18}$ added that enterprise motivation is a strong desire in an individual to prepare himself for work, to be aware that entrepreneurship is related to himself so that he will pay more attention and be willingly carry out entrepreneurship activities independently, be confident, be future oriented with the desire to be successful in the field according to his capability, strength, skills, and correct plan.

Entrepreneurship motivation affects enterprise behavior in three complementary ways, firstly the effect on an individual, which covers behavioral inclination and action intensity in entrepreneurship, secondly the importance of individual action and thirdly the persistent action to achieve the goal. ${ }^{19}$ Different motivation also affects entrepreneurship processes, for instance, man's perception of risks and chances in enterprise affect his decision to carry out business. ${ }^{20}$

There are many pieces of training to improve entrepreneurship motivation such as the research result done by Tentama, Mulasari, Maulana, and Anggraeni ${ }^{21}$ and Tentama, Mulasari, and Kusuma. ${ }^{22}$ This research differs in that it tries to improve entrepreneurship motivation through training of knowledge and skills in waste handling into charcoal briquets, liquid organic fertilizer and plant growing media. The training is expected to make the people understand the practical experience for entrepreneurship.

This research aimed at knowing how far the training of waste handling could improve the people's entrepreneurship motivation in Gondang Legi and Kepuh, Ngemplak district, Sleman regency, Yogyakarta special province. The research implied that the training of waste handling could improve the people's economy and could solve the pollution problem. For the government, it could be an alternative to improve the people's economic prosperity, and it could overcome environmental pollution in Sleman regency.

\section{RESEARCH METHOD}

\subsection{The Subject of the Research}

The research subject was 30 persons judged as an experimental group. The selection of the subject was done through a non-randomized technique, i.e., the purposive sampling in that the characteristic consideration selected them among others they were residents of Gondang Legi and Kepuh villages, unemployed, married for either men or women and were incapable of making use of waste for entrepreneurship.

\subsection{Measurement Instrument}

The scale to measure entrepreneurship motivation referred to individual characteristics of having desire and capability of doing entrepreneurship, which according to Meredith ${ }^{23}$ include selfconfidence, leadership, being innovative and creative, being task and output oriented, having broad vision and mission, and having risk taking characteristics.

$$
\text { (KE) } \mathrm{O}_{1} \Rightarrow \mathrm{X} \Rightarrow \mathrm{O}_{2}
$$

Fig. 1. Research design.

Notes: $\mathrm{KE}=$ Experimental group, $\mathrm{O} 1=$ Pre-test, $\mathrm{X}=$ Training of Waste Management, $\mathrm{O} 2$ = Post-test.

\subsection{Validity and Reliability of the Measurement Instrument}

The try out for measuring entrepreneurship motivation was given to 30 persons. The scale of entrepreneurship motivation consisted of 24 valid and reliable items. Corrected item-total correlation range from 0.305 to 0.630 , and the reliability coefficient was 0.861 . The instrument was suitable and can be used as an instrument for data collection in the research.

\subsection{Research Design}

The type of research was quasi-experimental. The experimental design used One-Group Pretest-Posttest Design, which used an experimental group only for the research by giving a pre-test and a post-test to the group. The different means of pre-test and posttest was then compared to know the level of entrepreneurship motivation so that the effect of the training of waste management in improving the people's entrepreneurship motivation.

\subsection{Procedure of Experiment}

The research was carried out in three phases, i.e., research preparation, research conduct, and research report. The first step, research preparation, some activities were done such as field survey, situational analysis, interview, literary research based on observation, and writing the research proposal. Before carrying out the research, the researchers designed research instruments to measure entrepreneurship motivation scales and then tried them out. The scale was used as the instrument for the research. The last phase of the research preparation was finding a research permit, coordinating with the subjects of the research about the procedure and the running of the study.

The phase of conducting the research covered carrying out the tryout of entrepreneurship motivation scale to get the instrument valid and reliable. The scale consisted of 24 items, and the scale was administered to 30 subjects as a tryout of the scale. After getting the data, they were analyzed using SPSS 17.0. And then the selected subjects with certain characteristics were grouped into an experimental group. They were the group, which would get the training.

The research accomplishment began as the research scale in the form of pre-test was given to the experimental group. The researcher provided the procedure how to fill up the size. The whole steps or sessions administered to the experimental group included.

Session 1. Filling up a pre-test form of entrepreneurship motivation. The subjects of the research were given explanations about how to fill up the measurement instrument and how to understand every question in the measurement instrument.

Session 2. The training of entrepreneurship motivation. The training aimed at improving the subjects' entrepreneurship motivation so that they would be strongly motivated to do entrepreneurship in handling waste to produce marketable products.

Session 3. The training of implementing entrepreneurship characters and values. The training tried to apply self-confidence, 
leadership, motives for innovation and creativity, the orientation of process and result, broad perspectives, and risk taking to the participants.

Session 4. The training of bio charcoal bricked making. The members were trained to make bio charcoal briquette from organic and non-organic (plastic HDPE etc.) and their use for everyday life using briquette stoves.

Session 5. The training of liquid fertilizer. The training of liquid fertilizer making from organic household waste was given to the participants. The training covered the way how to use the fertilizer for agriculture and garden plants.

Session 6. The training of growing-plant media. The training started from the practice of compost making from household waste as the raw material. The making of compost using composter was done after the waste was pierced using the piercing machine. The compost was used as plant-growing media.

Session 7. The training of 'Economic merit of the charcoal briquette, liquid organic fertilizer, and plant-growing media are marketable and improves briquette economy.

Session 8. Post-test scale data are taking. The researchers measured once again the subject entrepreneurship motivation after the training of waste management.

\subsection{Data Analysis}

To analyze the data the non-parametric statistic method was used. Wilcoxon test was used to know the different mean of the motivation level of the experimental group before and after the training. All computational calculation was done using SPSS 17.00 for windows.

\section{RESULTS AND ANALYSIS}

\subsection{Result}

The result of Wilcoxon analysis is shown in the following Tables I and II:

The table mentioned above shows that the Wilcoxon test result to know the mean difference of experimental group's entrepreneurship motivation before and after the training or the means of pre-test and post-test, i.e., $Z=-2.183$ for the pretest and 0.0145 (1-tailed) for the post-test with $p<0.05$.

This means there is a significant mean difference of entrepreneurship motivation before and after the training of waste management. The means of the motivation after the training is higher than before the training. The hypothesis, which says there is a mean difference of entrepreneurship motivation before and after the training of waste management is accepted.

\subsection{Analysis}

Kuratko, Hornsby dan Naffzigar ${ }^{24}$ reported that there had not been much empirical research on entrepreneurship motivation. Today many researchers are beginning to be interested in researching one's motivation to become an entrepreneur.

Table I. Descriptive statistics.

\begin{tabular}{lcccc}
\hline & \multicolumn{4}{c}{ Descriptive statistics } \\
\cline { 2 - 5 } & Mean & SD & Minimum & Maximum \\
\hline Posttest & 71.333 & 5.831 & 58 & 77 \\
Pretest & 67.833 & 4.190 & 60 & 75 \\
\hline
\end{tabular}

Table II. Result summary of Wilcoxon test.

\begin{tabular}{lccc}
\hline Source & $Z$ & $P$ & Noted \\
\hline Pretest-posttest & $-2,183$ & 0,0145 (1-tailed) & Significant \\
\hline
\end{tabular}

Entrepreneurship motivation can be grown through activities designed, for example through entrepreneurship motivation training. According to Eitington ${ }^{25}$ training is a means for individuals or groups of individuals to have the knowledge (knowledge), skills (skill), or certain behavior (behavior) to apply it in daily activities. The entrepreneurship motivation training is an activity that aims to improve and develop attitudes, behavior, skills, and knowledge of the community related to rural business opportunities and to encourage the community to conduct a series of activities that lead to the achievement of economic improvement.

The research result shows that the training of waste management can improve the entrepreneurship motivation of Gondang Legi and Kepuh villagers. The waste management training can be a solution to overcome the waste problem in the area. The condition of the people, whose entrepreneurship motivation to make use of waste was low at the beginning could be improved. Now they start to make use of the waste. They have been aware that the waste can be handled and changed into useful, marketable products. Previous similar researches in this area have also revealed the same thing. The researchers are done by Horng, ${ }^{26}$ and McClelland, ${ }^{27}$ show similar results. Tentama, Mulasari, and Kusuma ${ }^{22}$ that there is a significant difference of entrepreneurship motivation between the one before and after the training. The level of entrepreneurship motivation after the training is much higher than that before the training. This indicates that the provision of entrepreneurial training greatly affects entrepreneurship motivation in the form of the ability to sense business opportunities, initiatives to innovate and be creative, the drive to work hard, the overview in achieving goals, the ability to direct, to move, and to be responsible for improving the business and willingness to take risks.

Other research suggests that the training of recycling rice husk was effective and affected the improvement of the farmers' entrepreneurship motivation. By the knowledge, attitude, and the skill to become an entrepreneur, it is expected that they will be more self-confident, initiative, creative than before the training. The knowledge and skill also improve the farmers' point of view. Their perspective in making use of rice husk waste can improve their entrepreneurship motivation. ${ }^{21}$ Also, Rasheed, ${ }^{28}$ studies that the training and practice of entrepreneurship in America showed that people who received entrepreneurship training have higher motivation for entrepreneurship. Thus, the effective way to improve people's entrepreneurship motivation is to train them on waste management, which is oriented on their knowledge and skills in the area.

Entrepreneurship motivation is an important aspect of enterprise process. ${ }^{17}$ Entrepreneurship motivation correlates with an internal activity and energy release towards business creating. ${ }^{29}$

The improving enterprise motivation results in entrepreneurship behavior, which can affect people's economy improves. People will not handle waste if they have no initiative in it. ${ }^{1}$ Motivation to be the main capital for entrepreneurship, with the motivation of entrepreneurship, the individual will be encouraged to make efforts to utilize waste into a business opportunity that has a sale value to improve the economy and simultaneously as 
an effort to handle environmental pollution. Segal, Borgia, and Schoenfeld ${ }^{30}$ concludes that a person's decision to entrepreneurship or work for others is a rational process involving the following three aspects: Each person will compare the desirability to work independently or work for others, each person will judge whether he or she has knowledge, skills, and abilities to perform the tasks and activities required to become an entrepreneur, and each person must determine whether he is willing to accept the inherent risks in entrepreneurial activity.

Most people of Gondang Legi and Kepuh were jobless so that the training was advantageous for them. The consideration for the training was that there was a lot of waste, which could be the raw material for the making of the charcoal briquette, liquid organic fertilizer, and plat-growing media. The existence and the availability of waste became an important consideration for one to do entrepreneurship in the area. The training, furthermore, could enhance them to carry out the business. Waste has the potential to generate many benefits with a well-executed management process. Trash has the opportunity to be utilized and economic value. Utilization of waste among others is to be used as animal feed, composted, biogas, bioarang briquettes, recycled, sold directly, and reused. Another waste that can not be reused or recycled is only transported to landfills. ${ }^{31}$ The industrial goods produced in training are charcoal briquette, liquid organic fertilizer, and plant-growing media, which are marketable.

As an example charcoal briquette can produce higher heat than wood charcoal, more environmentally friendly, easier to use by people and do not require complex storage process. ${ }^{32}$ Oroka and Thelma $^{32}$ mention that briquettes can be a substitute for fuel oil, wood, and coal for household and small industries. Although in the manufacture of quality briquettes are not easy because of many factors such as the type of biomass, size, and density. ${ }^{33}$ Also, this type of adhesive also affects the quality of briquettes. ${ }^{34}$ Besides made briquette is also used as a medium of planting and organic fertilizer. To be a medium of planting and organic fertilizer, rice husk first made into the charcoal husk. The addition of charcoal husk can increase soil fertility because charcoal husk construction facilitates root to penetrate soil layer and produce pores in planting medium. These pores are useful for increasing the absorption of water, air, and nutrients. This is by the statement Fuhaid and Finahari ${ }^{35}$ that the husk is used one of them as a planting medium.

Waste is said to have economic value for market or to be processed into other industrial goods. ${ }^{36}$ Because of this, waste management based on the community can reduce the cost of waste disposal (TPA). Furthermore, it can benefit them. ${ }^{37}$ The training, which consists of 6 sessions as mentioned above and two other sessions (pre-test and post-test) can motivate people to do entrepreneurship in the area.

The result of the discussion and the interview after the training showed that the people were very interested in making use of the chance to do the business of handling household waste. The people had practiced the knowledge and skill to produce charcoal briquette. They were able to innovate it by modifying the mold for easy use, changing waste piercing instrument for piercing charcoal briquette and modifying the forms. This signified their high motivation in handling waste for business. One with high entrepreneurship motivation tends to be creative and innovative in his business as shown in Chen, $\mathrm{Wu}, \mathrm{Chen},{ }^{38}$ which shows a significant relationship between motivation and innovation.
This research differs from the previous researches in that this study uses organic and non-organic household waste as the raw material in making charcoal briquet, liquid organic fertilizer, and plant-growing media. The steps or phases in the research differ from the previous researches. They are by fulfillment aspects proposed by Meredith, ${ }^{23}$ which include self-confidence, having leadership behavior, being an initiative to innovate and to create things, being oriented to task and outcome, having the comprehensive perspective on mission and vision, and risk taking. The weaknesses of the research are it is time limited, the long term effect of the training cannot be seen for there is no follow up measurement due to the limited time and the absence of the control group in the research.

\section{CONCLUSION}

Based on the analysis, it can be concluded that the training of waste management can improve the entrepreneurship motivation of people in Gondang Legi and Kepuh, Sleman regency Indonesia. It is seen in the mean difference of enterprise motivation before and after the training of waste management.

The researchers recommend the followings: the research result shows that the training of waste management can help the people improve their entrepreneurship motivation so that it is recommendable to be an alternative for people's empowerment especially for jobless individuals in making use of waste in Sleman regency. For researchers interested in this area, it is advisable to carry out research with a control group and follow up measurement so that long-term effects of training can be perceived.

\section{References and Notes}

1. T. C. Kinnaman and D. Fullerton, Research Report the Nasional Science Foundation (1999).

2. A. W. Butu and Mshelia, British Journal of Environmental Sciences 2, 2 (2014).

3. D. Chikobnu and F. Makarati, Journal of Sustainable Development in Africa 13, 7 (2011).

4. S. Yelda and S. Kansai, Int. Journal Environmental and Pollution 19, 5 (2003).

5. M. Sharholy, K. Ahmad, G. Mahmood, and R. C. Trivedi, Waste Management 28 (2008).

6. O. O. Fafioye and John-Dewole, Greener Journal of Environmental and Management Studies 2, 2 (2013).

7. G. O. Ojo and D. M. Bowen, Journal of Sustainable Development in Africa 16, 1 (2014).

8. A. E. Prawira, liputan6.com/read/831280/sampah-tak-selalu-harus-dibuangtapi-bisa-menghasilkan (2016).

9. R. Setyawati and S. A. Mulasari, Kesmas 7, 12 (2013)

10. M. P. Hotagaol, Jurnal Manusia dan Lingkungan 16, 3 (2009).

11. N. Noosom, Southeast Asian J. Trop Med Public Health 36, 3 (2005).

12. C. Choe and I. Fraser, Journal of Enveronmental Economics and Management 38 (1999)

13. N. Ndidi, O. Nelson, O. Patricia, and J. Sunday, African Journal of Environmental Science and Tecnology 3, 12 (2009).

14. A. Botelho, International Journal of Chemical and Environmental Engineering System 3, 2 (2012).

15. WHO, Our Planet is Our Health, Gadjah Mada University Press (2001)

16. C. Estay, F. Durrieu, and M. Akhter, J. Int. Entrep. 11 (2013).

17. A. Carsrud and M. Brannback, Journal Small Bus Manag. 49 (2011)

18. B. Riyanti, Gramedia Widiasarana Indonesia (2003).

19. J. C. Braga, T. Proenca, and M. R. Ferreira, Review of Applied Management Studies 28 (2015)

20. S. Shane and S. Venkataraman, Academy of Management Review 25 (2000).

21. F. Tentama, S. A. Mulasari, M. Maulana, and R. Anggraeni, International Journal of Public Health Science 5 (2016).

22. F. Tentama, S. A. Mulasari, and R. K. Kusuma, Proceeding of Joint International Seminar (2016). 
23. G. G. Meredith, Pustaka Binaman Presindo (1996).

24. D. F. Kuratko, J. S. Hornsby, and D. W. Naffzigar, Journal of Small Business Management 35, 1 (1997).

25. J. E. Eitington, Gulf Publishing Company (1996)

26. S. C. Horng, Journal of Small Business Management 36 (1998).

27. D. C. McClelland, Massachusset, Boston (1995).

28. H. S. Rasheed, http://USASEB2001proceedings063 (2016).

29. P. Louart, Paris Economica (1997).

30. G. Segal, D. Borgia, and J. Schoenfeld, International Journal of Entrepreneurial Behaviour and Research 11, 1 (2005).

31. Basriyanta, Kanisius (2007).
32. F. O. Oroka and E. Thelma, Journal of Energy Tecnologies and Policy 3, 6 (2013).

33. S. J. Mitchual, K. F. Mensah, and N. Darkwa, International Journal of Energy and Environmental Engineering 4, 30 (2013).

34. I. Y. Zakari, A. Ismaila, U. Sidiq, and R. Nasiru, Journal of Natural Sciences Research 3, 12 (2013).

35. N. Fuhaid and N. Finahari, Jurnal Widya Teknika 16, 32 (2008).

36. Aryenti, Jurnal Pemukiman 6, 1 (2011).

37. C. Choe and L. Fraser, The Australian Journal of Agricultural and Resource Economics 43, 3 (1998)

38. S. C. Chen, M. C. Wu, and C. H. Chen, Journal Service Science and Management 3 (2010).

Received: 30 June 2017. Accepted: 16 September 2017. 